\title{
Rye Bread Fortified With Cellulose and Its Acceptance by Elderlies in Nursing Homes and Young Adults
}

\author{
Katharina Fuckerer ${ }^{1}$, Oliver Hensel ${ }^{2}$, Joachim J. Schmitt ${ }^{1}$ \\ ${ }^{1}$ Department of Food Technology, University of Applied Science Fulda, 36037 Fulda, \\ Germany \\ ${ }^{2}$ Faculty of Organic Agricultural Sciences, Department of Agricultural Engineering/Livestock \\ Systems Engineering, University of Kassel, 37213 Kassel, Germany \\ Correspondence: Katharina Fuckerer, Department of Food Technology, University of \\ Applied Science Fulda, Leipziger Straße 123, 36037 Fulda, Germany. Tel.: 49-(0)661-9640 \\ 541. E-mail: Katharina.Fuckerer@1t.hs-fulda.de
}

Received: Jan. 11, 2016 Accepted: Jan. 26, 2016 Published: December 1, 2016

doi:10.5296/jfs.v5i1.8847ＵRL: http://dx.doi.org/10.5296/jfs.v5i1.8847

\begin{abstract}
Several clinical studies suggest that a sufficient daily intake of fibres has positive effects on prevention of different diseases. Other studies show that most elderlies ingest too less fibres daily. As bread is one of the daily consumed food by elderly a brown rye bread fortified with three different cellulose fibres length $(18 \mu \mathrm{m}, 300 \mu \mathrm{m}, 700 \mu \mathrm{m})$ was developed. To find out whether elderly would consume such cellulose fortified rye breads, preference tests and a questionnaire about fibres and liking of fibres enriched rye breads were conducted with people older than 75 years and living in a nursing home. Comparable test were conducted with young adults. Preference test and questionnaire showed that young adults favoured rye bread with $18 \mu \mathrm{m}$ cellulose, because they associated soft crumb texture with freshly baked bread. Instead elderlies preferred standard rye bread and bread with $300 \mu \mathrm{m}$ cellulose, because those two kinds of rye breads have similar crumb texture which is popular with elderlies. These results showed that there are differences in preferring of fortified rye bread between elderlies and young adults. Parallel questionnaires showed that elderlies and young are well informed about fibres and have a positive attitude towards rye bread fortified with fibres. Therefore given information about fibres did not increase liking of the fibre rye breads. Finally, it can be concluded that elderlies would eat bread fortified with fibers and there were differences in liking of bread between elderlies and young.
\end{abstract}

Keywords: elderlies, rye bread, cellulose, preference test 


\section{Introduction}

Fibres are an important part of healthy nutrition. Several clinical studies suggest that a sufficient daily intake of fibres has positive effects on prevention of diabetes, coronary heart disease and constipation (Redgwell and Fisher, 2005, Thebaudin et al., 1997). Fibres are characterised in soluble and insoluble fibres. Cellulose belongs to the group of insoluble fibres, which raise the volume, weight and frequency of faeces, soften it and decrease transit time in the intestinal tract (Lattimer and Haub, 2010) and reduce the diabetes risk (Weickert and Pfeiffer, 2008). Despite of these positive effects, many people ingest not enough fibres daily, especially elderlies in nursing homes (Heseker and Stehle, 2008). Instead of recommended daily allowance of $30 \mathrm{~g}$ fibres (D-A-CH reference value, 2012) older men ingest just $15.1 \mathrm{~g}$ and older women only $12.7 \mathrm{~g}$ fibres a day (Heseker and Stehle, 2008).

This shows that daily eaten food may provide enough calories but not enough fibres. Changing this situation by nutritional advices for individuals and by media for the whole population did not succeed during the last decades. This proves that smarter ways are needed to bring the fibres to the people. One of this ways might be the enrichment of daily consumed food by fibres e. g. by adding them to bread. Bread is one of those products which most people eat day by day, up to $50 \mathrm{~kg}$ per year in Europe (FoB 2010). But bread enriched with fibres are hardly available as itis known that fibres change the baking properties of wheat breads, like loaf volume (Gan et al., 1992; Noort et al., 2010;Seguchi et al.,2007)and crumb firmness (Curti et al,. 2013; Gan et al., 1992; Wang et al., 2002).Furthermore elderlies often suffer from chewing and swallowing difficulties (Fillion and Kilcast, 2001) and wearing a dental prosthesis, which may complicate sometimes eating (Liedberg et al., 2005). As chewing properties affected the acceptance of bread (Heiniö, 2006), cellulose was also added to the rye bread in order to soften crumb texture. It was supposed that a soft crumb facilitated chewing and swallowing of bread and increase linking of fortified rye bread by elderlies.

All in all the aim of the study was to research how acceptance of fortified breads is by elderlies and students. Furthermore it was investigated whether there is a difference between elderlies ( $>75$ years) living in nursing homes and young adults in preferring of fortified bread and knowledge about fibres. Therefore three cellulose fibres with different length were baked into brown rye bread and were rated to preference by elderlies and students. Afterwards they had to fill in a questionnaire about fibre and acceptance of breads with fibres. Furthermore firmness of crumb texture was measured in order to find out whether soft crumb texture is favoured by elderlies.

\section{Material and Methods}

\subsection{Bread preparation}

Breads were baked under laboratory conditions following the formulation shown in table 1 . For bread with fibres three cellulose fibres (Vitacel ${ }^{\circledR}$ LC 600-10, LC 200, LC 1000, J. Rettenmaier \& Söhne GmbH \& Co.KG, Rosenberg, Germany) with different length (LC 600-10: $18 \mu \mathrm{m}$, LC 200: $300 \mu \mathrm{m}$, LC 1000: $700 \mu \mathrm{m}$ ) were used. Before cellulose fibres 
were added to the other ingredients, $118.6 \mathrm{~g}$ cellulose fibres were macerate in $200 \mathrm{~g}$ pre-warmed water $\left(37^{\circ} \mathrm{C}\right)$ for 5 Minutes.

Table 1. Bread formulation for two kilogram of dough

\begin{tabular}{l|rr|rr}
\hline \multicolumn{1}{c|}{ Ingredients } & \multicolumn{2}{|c|}{ Standard bread } & \multicolumn{2}{c}{ Bread with cellulose } \\
& Amount in g & Amount in \% & Amount in g & Amount in \% \\
\hline Rye flour type 997 & 830 & 41.5 & 678.9 & 33.9 \\
Wheat flour type 550 & 270 & 13.5 & 220.9 & 11.0 \\
Dry Auer (Diamalt) & 33 & 1.7 & 27.0 & 1.3 \\
Breadcrumbs & 23 & 1,2 & 18.8 & 0.9 \\
Yeast (S. cerevisiae) & 15 & 0.8 & 12.3 & 0.6 \\
Salt & 23 & 1.2 & 18.8 & 0.9 \\
Water (pre-warmed: $\left.37^{\circ} \mathrm{C}\right)$ & 806 & 40.3 & 904.7 & 45.2 \\
Cellulose fibres* & - & - & 118.6 & 5.9 \\
\hline
\end{tabular}

*cellulose fibres with different length: $18 \mu \mathrm{m}, 300 \mu \mathrm{m}, 700 \mu \mathrm{m}$

Ingredients were kneaded with the dough kneader (Typ S20G3, DIOSNA, Osnabrück, Germany) first for 5 minutes at Level 1 (60 strokes per minute) and a further 5 minutes at Level 2 (120 strokes per minute). Dough resting followed for 30 minutes at a temperature of $23^{\circ} \mathrm{C}$ and was afterwards covered with a moist cloth. The dough was split up into three parts of 800 g-portions. Each part was cylindrical kneaded and added to a fatted iron baking pan. Subsequently, the raw dough was incubated for one hour at $35^{\circ} \mathrm{C}$ and $80 \%$ humidity in the proofing cabinet (Typ AEG5, Fa. MIWE, Arnstein, Germany) for the rising process.

Standard breads and breads with cellulose fibres were baked in conventional oven (Type CE $416 / 77 \mathrm{H}$, Winkler Wachtel, Hilden, Germany). The Oven was heated to $200^{\circ} \mathrm{C}$ and the baking process took place for 50 minutes until the bread with crust had the core temperature of $95^{\circ} \mathrm{C}$. For the first 5 minutes the slide damper was open and steam was added for 5 seconds.

\subsection{Firmness}

Crumb firmness was measured using a TA-XT Plus texture analyser (Stable-Micro-Systems, Surrey, Great Britain), which measured maximal force in Newton. Slices of $25 \mathrm{~mm}$ were compressed $9.5 \mathrm{~mm}$ with a cylindrical probe (diameter: $35 \mathrm{~mm}$, contact: $962 \mathrm{~mm}^{2}$, cylinder aluminium) and with a test speed of $1.00 \mathrm{~mm} / \mathrm{sec}$. Three slices of two breads of each bread type were measured on three days.

\subsection{Sensory}

Hedonic evaluations of breads have been made from two groups, which differ in age. In the first sensory panel there were 39 elderly (mean age 82.9), which were older than 75 years old and lived in a nursing home in the near of Fulda. Second group consist of 40 students and staff of Fulda University of Applied Science (mean age: 24.8). Participants took part voluntary and were untrained. All panellists were not pregnant or breast-feed or were 
afflicted with diabetes mellitus, coeliac disease, nephropathy disease, chronic gastric and /or intestinal diseases. Panellists, who were allergic to one of the bread ingredients (e. g. yeast, rye, wheat) were not allowed to take part in hedonic evaluations. The study was approved by the Ethics Review Board at Fulda University of Applied Science.

The two panel groups had to evaluate four breads (standard bread and three breads with different cellulose fibre length) on a 5-point hedonic scale (1: very bad, 5: very good). The participant had to rate the appearance, odour, taste, texture and overall impressions of each bread. Every panellist got one slice of each bread with a thickness of $1.2 \mathrm{~cm}$. Samples were presented in random order and at room temperature. Bread samples were served on small plates, were coded with three-digit numbers and water was served for neutralization. All panellists didn't know that three of the breads were fortified with fibres.

\subsection{Questionnaire}

After evaluating breads each panellist got a semi standardised questionnaire with following generally questions, which they could answered with "Yes" or "No". This simple questionnaire was chosen, because the elderlies ( $>75$ years) should not be overstrained:

1. Would you like to eat bread, which is fortified with fibres?

2. Do you think you ingest enough fibres?

3. Do you know why fibres are important for your health?

After these questions it was explained that three of the breads were fortified with fibres and the three-digit numbers were called. Then the participants were asked in the questionnaire, if they would like to eat the three breads with fibres. Afterwards they received a flyer with information about importance of fibres, its positive impact to health and indications of deficient intake. Afterwards they were asked again, if they would like to eat the breads with fibres.

\subsection{Statistical Analysis}

All statistical analysis was calculated with SPSS ${ }^{\circledR}$ statistical software (Version 20.0, SPSS Inc., Chicago, USA). Statistical evaluation of preference tests and results of questionnaire were undertaken with Mann-Whitney-U-test $(p=0.05)$. The firmness values were analysed for significance using a one-way analysis of variance (ANOVA) with post hoc testing by Tukey-B test with a significance level of $p=0.05$. The mean values of firmness and volume are shown with standard deviations. Normal distribution was determined with Shapiro-Wilk-Test $(\mathrm{p}=0.05)$ and test of homogeneity of variance was passed by Levene Test $(\mathrm{p}=0.05)$.

\section{Results}

\subsection{Firmness}

Firmness values of the breads are presented in Table 2. Bread with $700 \mu \mathrm{m}$ cellulose fibres surfaced firmest texture and were significant different to the other breads. Bread with $18 \mu \mathrm{m}$ 
cellulose fibres showed the softest texture and differed significantly from the other breads. In contrast bread with $300 \mu \mathrm{m}$ cellulose fibres had similar firmness values like standard bread. Thus there was no significant difference between both bread types. It also could be determined that with rising cellulose fibres length the texture became firmer.

Table 2. Firmness values

\begin{tabular}{l|cccc}
\hline & Standard bread & $\begin{array}{c}\text { Bread with 18 } \boldsymbol{\mu m} \\
\text { cellulose fibres }\end{array}$ & $\begin{array}{c}\text { Bread with 300 } \boldsymbol{\mu m} \\
\text { cellulose fibres }\end{array}$ & $\begin{array}{c}\text { Bread with 700 } \boldsymbol{\mu m} \\
\text { cellulose fibres }\end{array}$ \\
\hline Firmness in N & $33.67 \pm 4.73 \mathrm{a}$ & $26.99 \pm 2.83 \mathrm{~b}$ & $33.18 \pm 2.94 \mathrm{a}$ & $38.42 \pm 3.81 \mathrm{c}$ \\
\hline
\end{tabular}

Mean S.D. values with different letters in the same row are significantly different $(\mathrm{p}<0.05)$.

\subsection{Sensory Evaluation}

Preference test results of the two panel groups constitute in Table 3. Elderlies as well as young adults gave appearance of standard bread best rating. But there were no significant difference between appearance of standard and other breads in elderly group. For young adults the appearance of standard bread and bread with $18 \mu \mathrm{m}$ cellulose fibres was significantly better than appearance of bread with $700 \mu \mathrm{m}$ cellulose fibres. But between both panels there were significant difference in appearance of standard bread, bread with $18 \mu \mathrm{m}$ and $300 \mu \mathrm{m}$ cellulose fibres. young adults assessed the appearance of all breads better than elderlies.

For young adults the odour of bread with $18 \mu \mathrm{m}$ cellulose fibres and for elderlies the odour of bread with $300 \mu \mathrm{m}$ cellulose fibres was the best one. In the group of elderlies the odour of bread with $300 \mu \mathrm{m}$ cellulose fibres was significantly different from bread with $700 \mu \mathrm{m}$ cellulose fibres. The odour evaluations between bread types didn't differ in young adult group. There were significant differences between the two panels in odour of bread with $18 \mu \mathrm{m}$ and $700 \mu \mathrm{m}$ cellulose fibres, but no differences in odour of standard bread and bread with $300 \mu \mathrm{m}$ cellulose fibres. All odour evaluations of elderlies were worse than young adults one.

The taste of standard bread was the best and taste of bread with $700 \mu \mathrm{m}$ fibres was worst for elderlies. But there were no significant differences between the tastes of all breads. In contrast young adults rated bread with $18 \mu \mathrm{m}$ fibres as best. Furthermore bread with $18 \mu \mathrm{m}$ fibres differed significantly from bread with $300 \mu \mathrm{m}$ and $700 \mu \mathrm{m}$ fibres by young adults. Likewise standard bread was significant different from bread with $700 \mu \mathrm{m}$ fibres. But there was no difference between bread with $18 \mu \mathrm{m}$ fibres and standard bread. Between the age groups the taste of bread with $18 \mu \mathrm{m}, 300 \mu \mathrm{m}$ and $700 \mu \mathrm{m}$ fibres as well as standard bread differed significantly. Young adults evaluated all breads better than elderlies.

Evaluation of texture showed that elderlies preferred standard bread and young adults preferred bread with $18 \mu \mathrm{m}$ fibres. Analysis of significance indicated that there is no difference between textures of all breads by elderly group. In contrast students rated breads significant different. So there were significant differences between bread with $18 \mu \mathrm{m}$ fibres and bread with $300 \mu \mathrm{m}$ and $700 \mu \mathrm{m}$ fibres. Also standard bread was significant different from 
bread with $700 \mu \mathrm{m}$ fibres. Anymore the evaluations of texture between elderlies and young adults differed significantly by bread with $18 \mu \mathrm{m}$ and $300 \mu \mathrm{m}$ fibres, but not by bread with $700 \mu \mathrm{m}$ fibres and standard bread. All texture ratings of young adults were higher than ratings of elderlies.

Elderlies evaluated standard bread as best and bread with $700 \mu \mathrm{m}$ fibres as worst in the category of overall impressions. Just standard bread and bread with $700 \mu \mathrm{m}$ differed significantly by elderlies. For young adultsbread with $18 \mu \mathrm{m}$ fibres were the best one in overall impression and also bread with $700 \mu \mathrm{m}$ fibres was the worst one in this category. Ratings of students differed only significantly between bread with $18 \mu \mathrm{m}$ fibres and bread with $700 \mu \mathrm{m}$ fibres. Evaluations of all breads showed significant differences between elderly and young adult group. Though elderlies rated with lower score all breads.

Summing up elderlies preferred standard bread in all categories with exception of odour, in which bread with $300 \mu \mathrm{m}$ fibres was the best one. Young adults favoured bread with $18 \mu \mathrm{m}$ in most of all categories with exception of appearance, in which standard bread was better. Both age groups rated bread with $700 \mu \mathrm{m}$ fibres as worst, except young adults in category of odour.

Table 3. Results of preference test

\begin{tabular}{|c|c|c|c|c|c|}
\hline & Appearance & Odour & Taste & Texture & Overall impressions \\
\hline \multicolumn{6}{|c|}{ Standard Bread } \\
\hline Elderlies & $3.47 \pm 0.72 \mathrm{a}$ & $3.28 \pm 0.78 \mathrm{ab}$ & $3.18 \pm 0.81 \mathrm{a}$ & $3.28 \pm 0.81 \mathrm{a}$ & $3.33 \pm 0.76 \mathrm{~b}$ \\
\hline Young adults & $4.15 \pm 0.61 \mathrm{a}$ & $3.58 \pm 0.70 \mathrm{a}$ & $3.68 \pm 0.82 \mathrm{ab}$ & $3.60 \pm 0.80 \mathrm{ab}$ & $3.70 \pm 0.75 \mathrm{ab}$ \\
\hline \multicolumn{6}{|c|}{ Bread with $18 \mu \mathrm{m}$ cellulose fibres } \\
\hline Elderlies & $3.16 \pm 0.93 \mathrm{a}$ & $3.13 \pm 0.72 \mathrm{ab}$ & $3.05 \pm 0.85 \mathrm{a}$ & $2.85 \pm 0.80 \mathrm{a}$ & $2.92 \pm 0.73 \mathrm{ab}$ \\
\hline Young adults & $4.03 \pm 0.88 \mathrm{a}$ & $3.73 \pm 0.71 \mathrm{a}$ & $4.05 \pm 0.59 \mathrm{a}$ & $4.03 \pm 0.72 \mathrm{a}$ & $3.98 \pm 0.57 \mathrm{a}$ \\
\hline \multicolumn{6}{|c|}{ Bread with $300 \mu \mathrm{m}$ cellulose fibres } \\
\hline Elderlies & $3.32 \pm 0.80 \mathrm{a}$ & $3.51 \pm 0.59 \mathrm{a}$ & $3.00 \pm 0.88 \mathrm{a}$ & $3.10 \pm 0.78 \mathrm{a}$ & $3.18 \pm 0.81 \mathrm{ab}$ \\
\hline Young adults & $3.83 \pm 0.83 \mathrm{ab}$ & $3.60 \pm 0.80 \mathrm{a}$ & $3.58 \pm 0.83 b$ & $3.53 \pm 0.89 \mathrm{~b}$ & $3.60 \pm 0.66 \mathrm{ab}$ \\
\hline \multicolumn{6}{|c|}{ Bread with $700 \mu \mathrm{m}$ cellulose fibres } \\
\hline Elderlies & $3.00 \pm 1.00 \mathrm{a}$ & $2.95 \pm 0.93 b$ & $2.74 \pm 1.06 \mathrm{a}$ & $2.74 \pm 0.93 \mathrm{a}$ & $2.79 \pm 0.94 \mathrm{a}$ \\
\hline Young adults & $3.48 \pm 0.89 b$ & $3.65 \pm 0.76 \mathrm{a}$ & $3.50 \pm 0.84 b$ & $3.10 \pm 0.99 b$ & $3.43 \pm 0.74 b$ \\
\hline
\end{tabular}




\subsection{Analysis of questionnaire}

Analysis of general questions is shown in Table 4. Though it is determined that $64.1 \%$ of elderlies and even $90.0 \%$ of young adults would eat bread, which is fortified with fibres. And yet $61.5 \%$ of elderlies and just $52.5 \%$ of young adults estimated that they ingest enough fibres daily. A great amount of elderlies (79.5\%) and even $97.5 \%$ of young adults know why fibres are important for health.

Table 4. Yes-answers of general questions

\begin{tabular}{lcc}
\hline & Elderlies & Young adults \\
\hline Would you like to eat bread fortified with fibres? & $71.8 \% \mathrm{a}$ & $90.0 \% \mathrm{~b}$ \\
Do you think that you ingest enough fibres? & $61.5 \% \mathrm{a}$ & $52.5 \% \mathrm{a}$ \\
Do you know why fibres are important for your health? & $79.5 \% \mathrm{a}$ & $97.5 \% \mathrm{~b}$ \\
\hline
\end{tabular}

Note: Values in the same row and subtable not sharing the same subscript are significantly different at $\mathrm{p}<0.05$.

After explaining, that three of four breads were fortified with fibres, the panellists had to decide, if they would eat these breads (Table 5). Most elderlies (53.9\%) preferred bread with $300 \mu \mathrm{m}$ fibres and most young adultsfavoured (83.0\%) bread with $18 \mu \mathrm{m}$ fibres. In general young adults would rather eat these fortified breads than elderlies. In both age groups least panellists would eat bread with $700 \mu \mathrm{m}$ fibres.

After reading the flyer about, what fibres are, what happens when eating too less and what positive effect fibres had to our health, the panellists were asked again, what fortified bread they would eat. All young adults and $89.7 \%$ of elderlies understood the flyer about fibres. Reading of the flyer influenced little student's choice of bread, because $2 \%$ and $5 \%$ more would eat bread with $18 \mu \mathrm{m}$ and $300 \mu \mathrm{m}$ fibres, respectively. In contrast acceptance of bread with $700 \mu \mathrm{m}$ did not change. Flyer affected acceptance of bread with $300 \mu \mathrm{m}$ and $700 \mu \mathrm{m}$ fibres in the group of elderlies, because agreement of these breads rose from $53.9 \%$ and $38.5 \%$ to $59.0 \%$ and $43.6 \%$, respectively. Acceptance of bread with $18 \mu \mathrm{m}$ was not influenced by the flyer in the elderly group. Still young adults preferred breads with fibres more than elderlies. 


\section{Macrothink}

Table 5. Yes-answers to breads fortified with fibres

\begin{tabular}{lll}
\hline & Elderlies & Students \\
\hline Knowing that breads fortified with fibres & & \\
Bread with $18 \mu \mathrm{m}$ cellulose fibres & $43.6 \% \mathrm{a}$ & $83.0 \% \mathrm{~b}$ \\
Bread with $300 \mu \mathrm{m}$ cellulose fibres & $53.9 \% \mathrm{a}$ & $60.0 \% \mathrm{a}$ \\
Bread with $700 \mu \mathrm{m}$ cellulose fibres & $38.5 \% \mathrm{a}$ & $50.0 \% \mathrm{a}$ \\
\hline After reading the flyer about fibres & & \\
Understanding of flyer about fibres & $89.7 \% \mathrm{a}$ & $100 \% \mathrm{~b}$ \\
Bread with $18 \mu \mathrm{m}$ cellulose fibres & $43.6 \% \mathrm{a}$ & $85.0 \% \mathrm{~b}$ \\
Bread with $300 \mu \mathrm{m}$ cellulose fibres & $59.0 \% \mathrm{a}$ & $65.0 \% \mathrm{a}$ \\
Bread with $700 \mu \mathrm{m}$ cellulose fibres & $43.6 \% \mathrm{a}$ & $50.0 \% \mathrm{a}$ \\
\hline
\end{tabular}

Note: Values in the same row and subtable not sharing the same subscript are significantly different at $\mathrm{p}<0.05$.

\section{Discussion}

\subsection{Preference test}

Preference test showed that there was a diversity of rating by breads with different fibres length and standard bread from elderlies and young adults. Elderlies favoured standard bread and bread with $300 \mu \mathrm{m}$ cellulose fibres. Gomez et al. (2003) showed in their study that bread without fibres is rated more positive than bread with fibres. In contrast students preferred bread with $18 \mu \mathrm{m}$ cellulose fibres. Both groups evaluated bread with $700 \mu \mathrm{m}$ cellulose fibres as worst, because small white pieces of cellulose fibres were seen by panellists and crumb texture was too firm. Zhang and Moore (1999) also determined that panellists rated wheat bread with fine wheat bran better than with coarse wheat bran in crumb texture, flavour and general acceptability.

It was assumed that elderlies preferred bread with a soften texture, because elderlies often suffered from chewing and swallowing difficulties (Fillion and Kilcast, 2001) and wearing a dental prosthesis, which complicate eating (Liedberg et al., 2005). Also chewing properties effected acceptance of bread (Heiniö, 2006). But although bread with $18 \mu \mathrm{m}$ fibres is softer than standard bread and bread with $300 \mu \mathrm{m}$ cellulose fibres, elderlies preferred standard bread and bread with $300 \mu \mathrm{m}$ cellulose fibres. Therefore it is supposed that elderlies favoured breads, which are similar with familiar bread.

Against it young adults favoured bread with softest texture, because they associated a soft crumb texture with freshly baked bread. In addition flavour, texture and freshness of bread is an important attribute for choice of bread (Heiniö, 2006). Summing up there are differences in liking of fortified fibre bread between elderlies and young adults. 


\subsection{Questionnaire}

Evaluation of common questions showed that young adults are more positive towards breads with fibres than elderlies. A reason for this might be that young adults are more informed about positive effects of fibres. But although most young adults knew importance of fibres they guessed that they ingest not enough fibres.

Like preference test has shown, the questionnaire demonstrated that most elderlies accepted bread with $300 \mu \mathrm{m}$ fibres and most young adults such with $18 \mu \mathrm{m}$ fibres. Elderlies preferred breads with $300 \mu \mathrm{m}$ fibres, because its texture is similar towards standard bread. Fewest of both groups would eat bread with $700 \mu \mathrm{m}$ fibres, because sensory properties of this fibre-enriched bread were not attractive enough for old and young participants. Frewer et al. (2003) reported that products with a desired positive effect to health but with poor sensory properties will not be purchased by consumers because consumers accept no losings in taste (Verbeke, 2006). That is why elderlies and young adults did not like bread with longest fibres length.

Given information about fibres influenced little acceptance of breads with fibres by both groups, because only less more accepted breads after reading these information. This could be due to already existing knowledge about fibres of both the students and the elderlies, so that these information were not new and did not influenced choice of bread.

\section{Conclusion}

Preference test showed that elderlies favoured standard bread and bread with $300 \mu \mathrm{m}$ cellulose fibres, because they are used to know standard bread and gave it best rating. Due to similarity of bread with $300 \mu \mathrm{m}$ cellulose fibres to standard bread in crumb texture, it was evaluated well by elderlies. In contrast young adults preferred bread with $18 \mu \mathrm{m}$ cellulose fibres, because they related soft crumb texture of this bread with freshly baked bread. So there are differences in liking of fibre rye bread between elderlies and young adults. These results were confirmed by the questionnaire of acceptance. Both elderlies and young adults disliked bread with $700 \mu \mathrm{m}$ cellulose fibres, because both groups evaluated appearance, odour, favour, texture and overall impression worst. Questionnaire also demonstrated that few participants would eat daily bread with large cellulose fibres.

Summing up elderlies would eat bread with cellulose fibres and there were differences in liking of breads between elderlies and young. Elderlies preferred standard bread and bread with $300 \mu \mathrm{m}$ cellulose fibers and young favored bread with $18 \mu \mathrm{m}$ cellulose fibers.

\section{Acknowledgement}

This project (HA project no. 359/12-49) was funded in the framework of Hessen Modell Projekte financed with funds of LOEWE-Landes-Offensive zur Entwicklung Wissenschaftlich-ökonomischer Exzellenz, Förderlinie 3: KMU-Verbundvorhaben from 01.08.2012 till 31.12.2014. 


\section{References}

Curti, E., Carini, E., Bonaicin G., Tribuzio G., \&Vittadini E. (2013). Effect of the addition of bran fractions on bread properties. Journal of Cereal Science, 57, 325-332. http://dx.doi.org/10.1016/j.jcs.2012.12.003

Deutsche Gesellschaft für Ernährung, Österreichische Gesellschaft für Ernährung, Schweizerische Gesellschaft für Ernährungsforschung, \& Schweizerische Vereinigung für Ernährung. (2012). Referenzwerte für die Nährstoffzufuhr. (1st ed.). Neustadt an der Weinstraße: Neuer Umschau Buchverlag.

Frewer, L., Scholderer, J., \&Lambert, N. (2003). Consumer acceptance of functional foods: issues for the future. British Food Journal, 105(10), 714-731. http://dx.doi.org/10.1108/00070700310506263

Fillion, L., \& Kilcast, K. (2001). Towards a measurement of oral tactile sensitivity and maticationperfor-mance: development of texture tests. Leatherhead Food RA Research Report, 781.

FoB. (2010). European Bread Market. Retrieved 9. March 2015, from http://www.bakersfederation.org.uk/the-bread-industry/industry-facts/european-bread-market. html.

Gan, Z., Galliard, T., Ellis, P.R., Angold, R.E., \& Vaughan, J.G. (1992). Effect of outer bran layers on the loaf volume of wheat bread. Journal of Cereal Science, 15, 151-163. http://dx.doi.org/10.1016/S0733-5210(09)80066-0

Gomez, M., Ronda, F., Blanco, C.A., Caballero, \& P.A. Apesteguía, A. (2003). Effect of dietary fibre on dough rheology and bread quality. European Food Research Technology, 216, $51-56$.

Heiniö, R.-L. (2006). Sensory attributes of bakery products. In Y. H. Hui (Ed.), Bakery products: science and technology (pp.285-298).Ames: Blackwell Publishing. http://dx.doi.org/10.1002/9780470277553.ch16

Heseker, H., \& Stehle, P. (2008). Ernährung älterer Menschen in stationären Einrichtungen (ErnSTES-Studie). Ernäherungsbericht 2008 der deutschen Gesellschaft für Ernährung e. V. (1st ed.). Bonn, 157-204.

Kock, de S., Taylor, J., \& Taylor, J.R.N. (1999). Effect of heat treatment and particle size of different brans on loaf volume of brown bread. Lebensmittel-Wissenschaft und -Technologie 32, 349-356. http://dx.doi.org/10.1006/fstl.1999.0564

Lattimer, J.M., \& Haub, M.D. (2010). Effects of Dietary Fiber and Its Components on Metabolic Health. Nutrients 2, 1266-1289; http://dx.doi.org/10.3390/nu2121266

Liedberg, B., Stoltze, K., \& Öwall, B. (2005). The masticatory handicap of wearing removable dentures in elderly men. Gerodontology, 22, 10-16. http://dx.doi.org/10.1111/j.1741-2358.2004.00050.x 


\section{Macrothink}

Journal of Food Studies

ISSN 2166-1073

2016, Vol. 5, No. 1

Noort, M.W.J., van Haaster, D., Hemery, Y., Schols, H.A., \& Hamer, R.J. (2010). The effect of particle size of wheat bran fractions on bread quality e Evidence for fibree protein interactions. Cereal Science 52(1), 59-64. http://dx.doi.org/10.1016/j.jcs.2010.03.003

Redgwell, R., \& Fisher, M.(2005). Dietary fibre as a versatile food component: an industrial perspective. Molecular Nutrition Food Research 49, 421-435. http://dx.doi.org/10.1002/mnfr.200500028

Seguchi M., Tabara, A., Fukawa, I., Ono, H., Kumashiro, C., Yoshino, Y., Kusunose C., \& Yamane, C. (2007). Effects of size of cellulose granules on dough rheology, microscopy, and breadmaking properties. Journal of Food Science 72(2), 79-84. http://dx.doi.org/10.1111/j.1750-3841.2007.00272.x

Thebaudin, J.Y., Lefebvre, A.C., Harrington, M., \& Bourgeois, C.M. (1997). Dietary fibres: Nurtritional and technological interest. Trends in Food Science \& Technology 8, 41-48. http://dx.doi.org/10.1016/S0924-2244(97)01007-8

Verbeke, W. (2006). Functional foods: consumer willingness to compromise on taste for health? Food Quality and Preference 17, 126-131. http://dx.doi.org/10.1016/j.foodqual.2005.03.003

Wang, J., Rosella, M.C., \& De Barbera, B.C. (2002). Effect of the addition of different fibres on wheat dough performance and bread quality. Food Chemistry 79, 221-226. http://dx.doi.org/10.1016/S0308-8146(02)00135-8

Weickert. M.O., \& Pfeiffer, A.F.H. (2008). Metabolic Effects of Dietary Fiber Consumption and Prevention of Diabetes. The Journal of Nutrition 138, 439-442. 